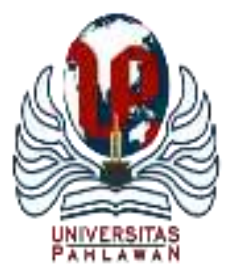

Edukatif : Jurnal Ilmu Pendidikan Volume 4 Nomor 1 Tahun 2022 Halm 1111 - 1118 EDUKATIF: JURNAL ILMU PENDIDIKAN

Research \& Learning in Education

https://edukatif.org/index.php/edukatif/index

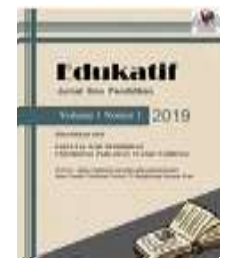

\title{
Peningkatan Kemandirian Santri Akselerasi di Pondok Pesantren
}

\author{
Nur Azizah Aulia Rahma ${ }^{1 凶}$, Suryanto ${ }^{2}$
}

Program Studi Magister Pengembangan Sumber Daya Manusia Sekolah Pascasarjana Universitar Airlangga ${ }^{1,2}$ E-mail : nur.azizah.aulia-2020@ pasca.unair.ac.id ${ }^{1}$, suryanto@ pasca.unair.ac.id ${ }^{2}$

\begin{abstract}
Abstrak
Pondok pesantren merupakan salah satu tempat belajar. Santri merupakan istilah bagi murid yang belajar di pondok pesantren. Santri bermukim di pondok dan tinggal terpisah dengan orang tuanya. Santri akan belajar dan mengasah kecakapan hidup (life skill) dan bertujuan agar santri lebih mandiri. Hal ini akan meningkatkan kemandirian. Penelitian ini bertujuan untuk mengetahui bagaimana model peningkatan kemandirian santri akselerasi di pondok pesantren Amanatul Ummah Surabaya. Pengumpulan data dilakukan dengan cara wawancara mendalam. Data yang didapat dianalis secara tematik sesuai tema wawancara. Hasil penelitian menunjukkan bahwa peningkatan kemandirian santri didasari oleh faktor internal dan faktor eksternal, serta terdapat 3 tahapan peningkatan kemandirian. Faktor internal meliputi hal-hal yang ada dalam diri santri, seperti pola pikir. Faktor eksternal meliputi hal-hal di luar diri santri, meliputi lingkungan dan pengalaman yang dimiliki. Sedangkan tahapan peningkatan kemandirian yaitu: pertama, tahap dasar, yaitu santri mampu mengatur dan bertanggungjawab terhadap dirinya sendiri. Kedua, tahap menengah, santri lebih berani di depan umum, berani menyampaikan argumentasi, dan mampu menyelesaikan masalahnya. Ketiga, tahap tertinggi, santri mampu diberikan amanah dan tanggungjawab bagi sekitarnya.
\end{abstract}

Kata Kunci: Kemandirian, Santri, Akselerasi.

\begin{abstract}
Islamic boarding school is a place of learning. Santri is a term for students who study in Islamic boarding schools. Santri live in boarding and live separately from their parents. Santri will learn and hone life skills and aim to make students more independent. This will increase independence. This study aims to determine how the model of increasing the independence of accelerated students at the Amanatul Ummah Islamic boarding school in Surabaya. Data was collected by means of in-depth interviews. The data obtained were analyzed thematically according to the theme of the interview. The results showed that increasing the independence of students was based on internal and external factors, and there were 3 stages of increasing independence. Internal factors include things that exist within students, such as mindsets. External factors include things outside the students themselves, including the environment and experiences they have. While the stages of increasing independence are: first, the basic stage, namely students are able to organize and be responsible for themselves. Second, in the middle stage, students are braver in public, dare to convey arguments, and are able to solve problems. Third, the highest stage, students are able to be given the mandate and responsibility for their surroundings.
\end{abstract}

Keywords: Independence, Santri, Acceleration.

Copyright (c) 2022 Nur Azizah Aulia Rahma, Suryanto

$\square$ Corresponding author

Email : nur.azizah.aulia-2020@pasca.unair.ac.id

DOI : https://doi.org/10.31004/edukatif.v4i1.1921

ISSN 2656-8063 (Media Cetak)

ISSN 2656-8071 (Media Online) 


\section{PENDAHULUAN}

Akselerasi merupakan program percepatan dalam menempuh pendidikan (Oka Sugiarta et al., 2016). Program ini di Indonesia umumnya diterapkan pada tingkat SMP/sederajat dan SMA/sederajat. Program akselerasi mengharuskan siswa mempelajari materi pembelajaran lebih cepat dari program reguler (Fitriani, 2016). Program pada jenjang menengah pertama dan menengah akhir pada umumnya ditempuh selama 3 tahun, namun pada program ini hanya ditempuh selama 2 tahun (Afianti, 2010). Menurut Hawadi (2004) dalam Purwati dan Akmaliyah (2016) menyebutkan akselerasi adalah kemajuan yang diperoleh dalam program pengajaran pada waktu yang lebih cepat atau dalam usia lebih muda dari umumnya. Tujuan dari program akselerasi adalah memberikan pelayanan untuk anak berbakat secara intelektual untuk dapat menyelesaikan masalah pendidikan lebih awal. Akselerasi (acceleration) secara singkat diterjemahkan sebagai "percepatan" dalam 2 pengertian, yaitu Akselerasi sebagai model layanan pembelajaran dengan cara melompat kelas, dan menunjukan pada peningkatan program sehingga dapat dijalankan dalam waktu lebih cepat dengan cara menganalisis materi pelajaran dengan mencari materi yang esensial (Haq \& Rahmah, 2020). Pendidikan merupakan proses penting pada kehidupan manusia, sebagai sarana peningkatkan kualitas berperilaku, berpikir, maupun bersikap (Zaenuri \& Prastowo, 2021). Pendidikan merupakan sistem yang saling terhubung.

Pondok pesantren merupakan salah satu lembaga pendidikan di Indonesia. Menurut Ulum (2018) pondok pesantren merupakan tempat belajar agama, para santri akan tinggal di pondok dan belajar bersama. Berbagai sistem pembelajaran diterapkan di pondok pesantren. Pondok pesantren salaf memiliki lebih banyak jam pembelajaran materi agama, seperti membaca kitab dan mengaji (Noor, 2015). Sedangkan pondok modern memadukan pembelajaran agama dengan kurikulum terbaru.

Selain belajar agama, di pondok pesantren para santri belajar untuk hidup mandiri. Santri tinggal di pondok dan jauh dari orang tua dan keluarga. Tempat kegiatan belajar merupakan tempat yang kondusif untuk menjalankan proses pendidikan dan pembelajaran nilai-nilai (Sari \& Firman, 2019). Pondok pesantren sebagai salah satu tempat belajar, juga memberikan pembelajaran dan nilai-nilai kehidupan. Santri belajar hidup mandiri dengan mengatur kehidupannya sendiri. UU Sisdiknas No. 20 Tahun 2003, disebutkan secara tersirat bahwa melalui pendidikan diharapkan potensi peserta didik dapat dikembangkan agar berani menghadapi problema kehidupan tanpa merasa tertekan, memiliki kemauan dan kemampuan, serta senang mengembangkan diri untuk menjadi manusia unggul (Purwati \& Akmaliyah, 2016). Melalui pendidikan juga diharapkan mampu mendorong peserta didik untuk memelihara diri sendiri, menyadarkan manusia sebagai hamba Tuhan Yang Maha Esa, memiliki kemandirian serta mampu menjalin hubungan dengan masyarakat dan lingkungan yang ada disekitarnya (Noor, 2015). Pembiasaan melakukan kegiatan yang dilakukan secara kontinu diharapkan memberikan dampak positif bagi peserta didik, karena setiap proses pembelajaran peserta didik senatiasa dimotivasi untuk memiliki karakter ataupun akhlak yang tangguh (Maria et al., 2021). Hal- hal tersebut dapat dilakukan di Pondok Pesantren sebagai tempat santri belajar mengatur dirinya.

Pada pondok pesantren Amanatul Ummah, sebagai salah satu pondok pesantren modern mengembangkan materi agama dan kurikulum terbaru. Pada pondok pesantren ini terdapat program akselerasi bagi para santri. Pada program ini, santri menempuh pendidikan selama 2 tahun, yakni lebih cepat daripada pendidikan pada program reguler. Hal ini memengaruhi kematangan emosional santri. Percepatan kelulusan tidak menentukan tingkat kedewasaan dan kemandirian mental santri (Uci Sanusi, 2012). Lulusan akselerasi memiliki umur yang lebih muda namun sudah mendapatkan beban yang sebanding dengan tingkat kelas yang dijalankannya. Pada umumnya, teman sebaya santri akselerasi berada pada tingkat di bawah santri akselerasi. Hal ini yang menjadikan beban santri akselerasi berbeda meskipun pada umur yang sama (Andharini \& Nurwidawati, 2015).

Pembelajaran di pondok pesantren dapat meningkatkan kemandirian santri (Naelasari, 2020). Seluruh kegiatan sehari-hari dilakukan sendiri. Meskipun demikian, guru sebagai tenaga pendidik juga memiliki peran 


\section{Peningkatan Kemandirian Santri Akselerasi di Pondok Pesantren - Nur Azizah Aulia Rahma, Suryanto DOI: https://doi.org/10.31004/edukatif.v4i1.1921}

dalam pengembangan kemandirian (Laili, 2021). Beberapa guru dan pembimbing hanya mengingatkan sekali ataupun dua kali. Santri yang tinggal di pondok akan meningkat kemandiriannya karena harus mengatur jadwal terhadap dirinya sendiri.

\section{METODE PENELITIAN}

Penelitian merupakan penelitian deskriptif dengan pendekatan kualitatif. Penelitian deskriptif kualitatif yaitu penelitian yang dideskripsikan dengan kata dan meneliti fenomena (Usman, n.d.). Penelitian ini menggunakan metode kualitatif dengan pendekatan deskriptif. Jenis penelitian ini adalah kualitatif, yaitu berdasarkan pada data yang muncul berwujud kata-kata dan bukan rangkaian angka, dan tergolong dalam perspektif yang artinya melukiskan variabel demi variabel satu demi satu agar diperoleh data yang lebih valid dan menyeluruh. Partisipan dalam penelitian ini adalah santri akselerasi yang mondok atau belajar di Pondok Pesantren Amanatul Ummah. Partisipan merupakan santri yang mengenyam pendidikan tingkat MA pada program Akselerasi. Pengumpulan data diperoleh dengan observasi, wawancara semi terstruktur dan mendalam. Teknik pengambilan data menggunakan wawancara semi terstruktur yang memungkinkan peneliti dan partisipan untuk berdialog secara mandiri dan mendalam khususnya mengenai bagaimana model peningkatan kemandirian santri akselerasi. Peneliti terlibat langsung pada proses observasi dan wawancara. Tahapan dilakukan mulai dari observasi awal di lokasi, melalukan perizinan dan penyelesaian instrument penelitian. Penelitian ini dilakukan mulai April 2021 hingga Juni 2021. Analisis data dilakukan pada bulan Juni 2021. Pada penggalian data melalui wawancara, hasil wawancara dikumpulkan melalui rekaman. Analisis data menggunakan model interaktif Miles dan Huberman yaitu pengumpulan data, reduksi data, penyajian data dan penarikan kesimpulan.

\section{HASIL DAN PEMBAHASAN PENELITIAN}

\section{A. Deskripsi “Kemandirian" Santri Akselerasi di PP. Amanatul Ummah}

Kemandirian merupakan hal mendasar yang dipelajari di pondok pesantren. Semua anak yang mengenyam pendidikan di pondok pesantren tentu akan sedikit banyak belajar tentang konsep kecakapan hidup (life skill), salah satunya adalah kemandirian. Tantangan zaman yang terus berkembang, membuat guru perlu menyiapkan anak untuk siap menghadapinya (Maladerita et al., 2021). Tidak menutup kemungkinan secara jumlah umur santri akselerasi terbilang lebih muda dibandingkan dengan teman sebaya pada tingkat kelas yang sama (Noor, 2015). Kemandirian dapat dilihat dari perilaku sehari-hari, cara berpikir dan bertindak, serta cara menyelesaikan masalah yang dihadapi (Junaidi \& Fildza Avisyah, 2020). Kemandirian seseorang dapat berkembang apabila diberikan kesempatan untuk berkembang sejak dini melalui pelatihan yang dilakukan secara kontinu (Wijaya, 2015).

Menurut Steinberg (1995) dalam (Noor, 2015) memberikan definisi kemandirian yaitu, suatu kondisi di mana seorang tidak tergantung pada orang lain dalam menentukan keputusan dan adanya sikap kepercayaan diri. Konsep kemandirian sebagai self governing person, yakni kemampuan menguasai diri sendiri. Secara psikososial kemandirian tersusun dari tiga dimensi pokok yaitu: (a) Kemandirian emosi (emotional autonomy) yaitu aspek yang berhubungan dengan perubahan kedekatan/keterikatan hubungan emosional individu, terutama sekali dengan orang tua, (b) Kemandirian bertindak (behavioral autonomy) yaitu aspek kemampuan untuk membuat keputusan secara bebas dan menindaklanjutinya dan (c) Kemandirian nilai (value autonomy) yaitu aspek kebebasan untuk memaknai seperangkat prinsip tentang benar dan salah, yang wajib dan yang hak, apa yang penting dan apa yang tidak penting.

Erickson (1999) dalam Suci Pangestu (2017) menyatakan bahwa kemandirian adalah usaha untuk melepaskan diri dari orang tua dengan maksud untuk menemukan dirinya sendiri melalui proses mencari identitas ego, yaitu merupakan perkembangan ke arah individualis yang mantap dan berdiri sendiri. 
Kemandirian biasanya ditandai dengan kemampuan menentukan nasib sendiri, kreatif, dan inisiatif, mengatur tingkah laku, bertanggung jawab, mampu menahan diri, membuat keputusan-keputusan sendiri, serta mampu mengatasi masalah tanpa ada pengaruh dari orang lain. Kemandirian dapat dipengaruhi oleh lingkungan sekitarnya (Aulia, Susilo, dan Subali 2019).

Robert Havighurst (1972) dalam (Desmita, 2014) membagi kemandirian menjadi 4 bentuk antara lain sebagai berikut:

a. Kemandirian emosi, yaitu kemampuan mengontrol emosi sendiri dan tidak tergantungnya emosi pada orang lain.

b. Kemandirian ekonomi, yaitu kemampuan mengatur ekonomi sendiri dan tidak tergantungnya kebutuhan ekonomi pada orang lain.

c. Kemandirian intelektual, yaitu kemampuan untuk mengatasi berbagai masalah yang dihadapi.

d. Kemandirian sosial, yaitu kemampuan untuk mengadakan interaksi dengan orang lain dan tidak bergantung pada aksi orang lain.

Pendidikan life skill di pondok pesantren Amanatul Ummah bertujuan untuk meningkatkan pengetahuan dan keterampilan santri agar memiliki kemampuan menghadapi segala tantangan secara mandiri. Berdasarkan data yang didapat di lapangan, diketahui bahwa model peningkatan kemandirian santri didasari dari 2 faktor, yaitu faktor internal dan faktor eksternal. Faktor internal merupakan faktor yang berasal dari diri santri. Sedangkan faktor eksternal merupakan faktor yang memengaruhi kemandirian santri dari luar dirinya, diantaranya seperti komponen pendidikan, sarana, lingkungan, proses berorganisasi, hasil dan dampak pembelajaran, dan sistem pengajaran. Faktor internal meliputi pengalaman, pengetahuan, dan prinsip yang dipahami oleh santri. Beberapa nasehat guru juga memengaruhi pola pikir santri, hal ini dapat meningkatkan kemandirian santri. Berdasarkan wawancara di lapangan dengan santri A, ditemukan bahwa seorang santri yang mandiri memiliki ciri-ciri sebagai berikut:

"Santri yang mandiri itu merupakan santri yang sudah dapat mengatur dirinya baik secara emosi dan kedisiplinan keseharian. Santri yang mandiri mampu menyelesaikan tugas-tugasnya, mengikuti kegiatan secara disiplin, mengatur dirinya dan lingkungannya, serta mampu menyelesaikan permasalahan yang dihadapi." (AK).

Pendapat di atas menyatakan bahwa kemandirian dapat ditunjukkan dengan sikap dan pola pikir yang dimiliki santri. Kemandirian dapat diasah dan ditingkatkan lagi. Sependapat dengan jawaban santri A, santri B juga menyatakan hal yang serupa:

"Menurut kami, santri yang mandiri adalah yang mampu mengatur dirinya, tidak bergantung pada orang lain, dan sudah mengerti jadwal sehingga tidak perlu sering diingatkan. Hal ini saya dapatkan dari pembiasaan di organisasi yang saya ikuti." (MA)

Bagi santri akselerasi, penyesuaian kemandirian di pondok pesantren membutuhkan waktu serta pemahaman yang berbeda dengan santri seusianya pada lembaga lainnya. Hal tersebut dapat dilihat dari pola pikir, sikap, dan cara penyelesaian masalah pada santri akselerasi. Adapun perbedaan santri akselerasi dengan santri pada program lainnya di pondok pesantren Amanatul Ummah dapat dilihat pada tabel berikut: 
1115 Peningkatan Kemandirian Santri Akselerasi di Pondok Pesantren - Nur Azizah Aulia Rahma, Suryanto DOI: https://doi.org/10.31004/edukatif.v4i1.1921

Tabel 1 : Perbedaan Kemandirian Santri

\begin{tabular}{|c|c|c|}
\hline Perbedaan & Santri Akselerasi & Santri Unggulan (program lain) \\
\hline Masa Pembelajaran & 2 tahun & 3 tahun \\
\hline Kemandirian Emosi & $\begin{array}{l}\text { Belum dapat mengontrol emosi } \\
\text { dengan bijak. } \\
\text { membutuhkan arahan } \\
\text { bimbingan guru }\end{array}$ & $\begin{array}{l}\text { Sudah cukup mampu mengontrol } \\
\text { emosi sendiri. }\end{array}$ \\
\hline $\begin{array}{l}\text { Kemandirian } \\
\text { Intelektual }\end{array}$ & $\begin{array}{l}\text { Belum cukup dewasa, kekanak- } \\
\text { kanakan. Membutuhkan bantuan } \\
\text { guru untuk menyelesaikan } \\
\text { masalah. }\end{array}$ & $\begin{array}{l}\text { Cukup dewasa namun tetap } \\
\text { membutuhkan arahan. Berupaya } \\
\text { menyelesaikan masalah sendiri }\end{array}$ \\
\hline Kemandirian Sosial & $\begin{array}{l}\text { Masih membutuhkan arahan } \\
\text { secara detail. Belum bisa } \\
\text { sepenuhnya diberikan } \\
\text { kepercayaan dan dilepaskan }\end{array}$ & $\begin{array}{l}\text { Sudah mulai menunjukkan sikap } \\
\text { kedewasaan, tidak suka diatur } \\
\text { secara detail. Lebih suka diberi } \\
\text { kepercayaan dari suatu kegiatan. }\end{array}$ \\
\hline
\end{tabular}

Sumber: diolah dari hasil analisis data

Dari beberapa pendapat di atas serta analisis data yang ada, dapat disimpulkan bahwa pemahaman konsep kemandirian santri dapat dilihat dari pola pikir, sikap, perilaku, dan empati sosialnya. Santri yang mandiri sudah dapat mengatur dirinya sendiri, baik dari jadwal kegiatan maupun menempatkan diri dalam segala kondisi. Selain itu juga sudah memiliki pola pikir yang dewasa, dengan tidak bergantung pada orang lain. Serta sudah mampu menyikapi lingkungan disekitarnya dan menyelesaikan masalah yang dihadapinya.

Dari uraian diatas dapat disimpulkan bahwa yang dimaksud dengan peningkatan kemandirian santri melalui penyelenggaraan life skill di pesantren adalah usaha sadar dan terencana untuk mewujudkan suasana belajar dan proses pembelajaran di pondok pesantren agar para santri secara aktif mengembangkan potensi dirinya untuk memiliki keterampilan bekerja atau usaha mandiri.

\section{B. Peningkatan Kemandirian Santri Akselerasi di PP. Amanatul Ummah}

Setiap anak akan mengalami fase perkembangan dalam kehidupannya. Begitu pula santri yang tinggal di pondok pesantren. Sistem pembelajaran serta kegiatan yang membuat santri melatih kemandiriannya, akan mampu mengembangkan sikap mandiri yang sudah dimilikinya. Faktor internal dan eksternal menunjang peningkatan kemandirian santri. Lingkungan dan sosial yang mendukung adanya peningkatan kemandirian mampu membuat santri semakin mandiri.

Jika dikaitkan dengan pondok pesantren, metode pengembangan kemandirian yang sering dilakukan pesantren, diantaranya:

a. Menanamkan prinsip kemandirian dalam proses pembelajaran (pengajian) dan kurikulum.

b. Membekali berbagai macam keterampilan (life skill) bagi santri.

c. Memberikan bekal pengetahuan kepemimpinan (leadership) dan mengarahkan aplikasinya

d. Menerapkan cara hidup penuh ikhtiar, sabar dan tidak mengandalkan cara hidup instan.

Hasil wawancara dengan santri $\mathrm{C}$ menyebutkan bahwa salah satu faktor yang mendukung peningkatan kemandirian santri adalah hidup jauh atau terpisah dengan orang tua, sehingga mereka dapat menentukan pilihan dalam hidupnya. Santri C berpendapat:

"Salah satu hal terbesar yang memengaruhi peningkatan kemandirian santri adalah karena hidup berpisah dengan orang tua dan keluarga. Serta mengikuti kegiatan-kegiatan di pondok. Berpisah dengan orang tua membuat kami mau tak mau menentukan apa yang harus kami lakukan," (AR). 
Selain pendapat diatas, santri D memiliki pendapat lain yang menambahkan pendapat sebelumnya. Menurut santri D berpendapat bahwa lingkungan sekitar atau teman, serta amanah atau tanggung jawab yang diberikan juga dapat meningkatkan kemandirian santri. Pendapat santri D yaitu:

"Ketika kami hidup bersama teman-teman dan jauh dari orang tua itu dapat meningkatkan kemandirian. Amanah dari guru dan pembimbing seperti tanggung jawab di suatu kegiatan dan organisasi, itu juga membuat kami semakin mandiri, karena bisa melakukan sendiri," (RG).

Kemandirian yang dicapai santri selama di pondok pesantren berlangsung tidak sekaligus, akan tetapi secara bertahap dimulai dari kemandirian dasar, meningkat ke tahap kemandirian menengah dan selanjutnya santri mencapai kemandirian tinggi yang ditandai dengan pemberian tanggung jawab dan kewenangan oleh kyai sebagai santri senior.

Secara umum tahapan pencapaian kemandirian santri serta indikator kemandirian yang dicapai santri dapat dilihat pada tabel Tahapan Pencapaian Kemandirian Santri berikut ini.

Tabel 2: Indikator Kemandirian Santri

\begin{tabular}{|c|c|c|}
\hline Tahapan Pencapaian & Indikator Kemandirian & $\begin{array}{l}\text { Model Peningkatan } \\
\text { Kemandirian }\end{array}$ \\
\hline Kemandirian Tinggi & $\begin{array}{l}\text { Santri berapa pada tahap } \\
\text { pemantapan: } \\
\text { - Santri mendapat amanah } \\
\text { dan tanggung jawab dari } \\
\text { guru ataupun pembimbing } \\
\text { pondok } \\
\text { - Memiliki prinsip dalam } \\
\text { hidup yang dijalankan }\end{array}$ & $\begin{array}{l}\text { Santri diberi tanggungjawab } \\
\text { atau amanah untuk menjalankan } \\
\text { suatu acara maupun } \\
\text { kepengurusan secara mandiri. } \\
\text { Guru, pembimbing, dan } \\
\text { pengasuh mengontrol. }\end{array}$ \\
\hline Kemandirian Menengah & $\begin{array}{l}\text { Santri berada pada tahap } \\
\text { perkembangan: } \\
\text { - Santri sudah mampu } \\
\text { menyelesaikan } \\
\text { permasalahannya sendiri } \\
\text { - Santri memiliki semangat } \\
\text { untuk berargumentasi } \\
\text { - Santri memiliki sikap } \\
\text { disiplin dan tanggung jawab } \\
\text { segala hal }\end{array}$ & $\begin{array}{l}\text { - Santri diberikan kesempatan } \\
\text { untuk menyampaikan } \\
\text { pendapatnya pada kegiatan } \\
\text { diskusi. } \\
\text { - Santri diberikan kesempatan } \\
\text { tampil di depan umum }\end{array}$ \\
\hline Kemandirian Dasar & $\begin{array}{l}\text { Santri beradaptasi dengan } \\
\text { lingkungan sekitarnya: } \\
\text { - Mulai dapat mengatur dan } \\
\text { mengurus dirinya sendiri } \\
\text { - Mulai bertanggung jawab } \\
\text { terhadap yang dilakukannya } \\
\text { - Bersosialisasi dan } \\
\text { berinteraksi dengan teman } \\
\text { sebaya ataupun kakak } \\
\text { kelasnya }\end{array}$ & $\begin{array}{l}\text { - Santri diberikan arahan, } \\
\text { dan diberikan kesempatan } \\
\text { mengatur dirinya sendiri }\end{array}$ \\
\hline
\end{tabular}


Berdasarkan data temuan di atas, dapat diketahui bahwa kemandirian santri memiliki beberapa tahap. Kemandirian yang mendasar dimulai dari dapat mengatur dirinya sendiri. Peran pemahaman diri dan pengalaman cukup berpengaruh pada tahap ini. Karena santri akan menentukan tindakan yang dilakukannya, seperti mengikuti jadwal kegiatan. Pada tahap selanjutnya adalah kemandirian menengah, yakni santri lebih memiliki keberanian di depan umum seperti menyampaikan argumentasi atau tampil di depan umum. Selain itu juga santri sudah mampu menyelesaikan permasalahan dan tantangan yang dihadapinya secara mandiri.

Tahap terakhir adalah kemandirian tertinggi, dimana santri sudah mulai mengemban amanah dan bertanggung jawab atas suatu hal yang lebih besar. Tidak hanya bertanggungjawab pada dirinya sendiri, tetapi juga mendapat amanah atau tugas di pondok pesantren, seperti menjalankan suatu acara atau masuk dalam kepanitiaan kegiatan besar.

Model peningkatan kemandirian santri di pondok pesantren Amanatul Ummah dengan memberikan tanggungjawab pada santri. Pada mulanya, santri diberikan tanggungjawab atas dirinya. Santri mengatur segala aktivitas yang akan dilakukannya, mulai dari bangun tidur hingga tidur lagi. Seperti aktivitas salat berjamaah, mengaji, dan belajar di sekolah. Selanjutnya santri diberikan kesempatan untuk tampil di depan umum maupun menyampaikan argumentasinya. Santri juga diberikan kesempatan untuk menyelesaikan permasalahan yang dihadapinya. Semakin bertambah kedewasaan santri, akan diberikan amanah dan tanggung jawab oleh guru dan pembimbing.

\section{KESIMPULAN}

Berdasarkan data yang dikumpulkan pada penelitian ini dapat disimpulkan bahwa santri akselerasi secara usia dan tingkat kedewasaan berbeda dengan santri pada program lain. Hal ini disebabkan karena masa pembelajaran pada program akselerasi lebih cepat dibandingkan program lainnya. Pembelajaran di pondok pesantren mengembangakn kecakapan hidup (life skill) yang bertujuan agar santri dapat bersikap mandiri. Ciri-ciri santri mandiri dapat dilihat dari pola pikir, perilaku, sikap, dan cara penyelesaian masalah yang dihadapinya. Terdapat berbagai faktor yang mendukung peningkatan kemandirian santri, yaitu faktor internal (dari dalam dirinya) dan faktor eksternal (diluar dirinya). Salah satu faktor yang paling berpengaruh adalah karena hidup terpisah dari orang tua dan keluarga serta amanah dan tanggung jawab yang diberikan. Adapun tahapan kemandirian terdapat 3 tahapan, yaitu tahap dasar, tahap menengah, dan tahap tertinggi. Tahapan kemandirian dimulai dari santri dapat mengatur dan betanggungjawab atas dirinya sendiri. Tahap selanjutnya, santri berani tampil di depan umum dan menyampaikan argumentasinya, serta mampu menyelesaikan permasalahan yang dihadapinya. Tahap tertinggi yakni santri mampu mengemban amanah dan tanggung jawab yang diberikan guru, pembimbing, atau pengasuh pondok pesantren.

\section{UCAPAN TERIMA KASIH}

Ucapan terima kasih secara khusus penulis sampaikan kepada santri MA Program SKS Amanatul Ummah Surabaya yang telah membantu dalam pengumpulan data. Terima kasih disampaikan untuk Sekolah Pascasarjana Universitas Airlangga yang telah memberikan dukungan kepada penulis.

\section{DAFTAR PUSTAKA}

Afianti, R. (2010). Hubungan Antara Self Regulated Learning (Srl) Dengan Kemandirian Pada Siswa Program Akselerasi. Thesis Universitas Diponegoro, 1-19.

Andharini, A., \& Nurwidawati, D. (2015). Hubungan Antara Dukungan Sosial Dengan Stres Pada Siswa Akselerasi. Character, 03(2), 1-5.

Aulia, L. N., Susilo, S., \& Subali, B. (2019). Upaya Peningkatan Kemandirian Belajar Siswa Dengan Model 
1118 Peningkatan Kemandirian Santri Akselerasi di Pondok Pesantren - Nur Azizah Aulia Rahma, Suryanto DOI: https://doi.org/10.31004/edukatif.v4i1.1921

Problem- Based Learning Berbantuan Media Edmodo Efforts To Increase Student Self-Regulated Learning With Problem-Based Learning Model Use Edmodo. Jurnal Inovasi Pendidikan Ipa, 5(1), 6978.

Desmita. (2014). Psikologi Perkembangan Peserta Didik. Badung. Pt. Remaja Rosdakarya.

Fitriani, A. (2016). Interaksi Sosial Siswa Akselerasi Dan Siswa Reguler Smp Negeri 2 Pangkajene Kabupaten Pangkep. Jurnal Sosialisasi Pendidikan Sosiologi-Fis Unm, 3(2), 136-142. Http://Ojs.Unm.Ac.Id/Sosialisasi/Article/View/2376.

Haq, I., \& Rahmah, M. (2020). Training Manajemen Diri Pada Siswa Akselerasi Man 1 Malang. Altruis Journal Of Community Services, 1(1), 39-56.

Junaidi, J., \& Fildza Avisyah. (2020). Peningkatan Kemandirian Santri Berbasis Nilai Religius Di Pesantren. Edupedia, 4(2), 71-79. Https://Doi.Org/10.35316/Edupedia.V4i2.667.

Laili, N. (2021). Edukatif: Jurnal Ilmu Pendidikan Upaya Guru Pai Dalam Meningkatkan Kemampuan Kognitif Siswa Pada Mata Pelajaran. 3(4), 1437-1445.

Maladerita, W., Septiana, V. W., Gistituati, N., Bentri, A., Doktor, P., Pendidikan, I., \& Negeri, U. (2021). Peran Guru Dalam Menerapkan Kurikulum 2013 Di Sekolah Dasar. Edukatif: Jurnal Ilmu Pendidikan, 3(6), 4771-4776.

Maria, R., Rifma, R., \& Syahril, S. (2021). Efektivitas Pembelajaran Dan Pembinaan Karakter Di Masa Pandemi Covid-19. Edukatif: Jurnal Ilmu Pendidikan, 3(4), 1503-1512.

Naelasari, D. (2020). Implementasi Pendidikan Life Skill Dalam Pembentukan Kemandirian Santri (Studi Kasus Di Pondok Pesantren Al Urwatul Wutsqo). E-Journal Universitas Darul Ulum Lamongan, 8 , 274-282.

Noor, A. H. (2015). Pendidikan Kecakapan Hidup (Life Skill) Di Pondok Pesantren Dalam Meningkatkan Kemandirian Santri. Empowerment, 3(1), 2252-4738. Www.Journal.Uta45jakarta.Ac.Id.

Oka Sugiarta, G. P., Widiana, I. W., \& Kade Tastra, I. D. (2016). Penerapan Model Pembelajaran Akselerasi (Accelerated Learning) Untuk Meningkatkan Hasil Belajar Ipa Siswa Kelas V. E-Journal Pgsd Universitas Pendidikan Ganesha, 6(3), 1-10.

Purwati, E., \& Akmaliyah, M. (2016). Hubungan Antara Self Efficacy Dengan Flow Akademik Pada Siswa Akselerasi Smpn 1 Sidoarjo. Psympathic: Jurnal Ilmiah Psikologi, 3(2), 249-260. Https://Doi.Org/10.15575/Psy.V3i2.1113.

Sari, L., \& Firman, F. (2019). Pengembangan Model Pendidikan Karakter Terintegrasi Pembelajaran Ipa Sekolah Dasar. Edukatif: Jurnal Ilmu Pendidikan, 1(3), 270-279. Https://Doi.Org/10.31004/Edukatif.V1i3.64.

Suci Pangestu, D. (2017). Kemandirian Anak Dalam Pembelajaran Pengembangan Sosial Emosional (Studi Deskriptif Kuantitatif Di Paud Assalam Muara Bangkahulu Kota Bengkulu). Jurnal Ilmiah Potensia, 2(146), 86-90.

Uci Sanusi. (2012). Pendidikan Kemandirian Di Pondok Pesantren: Studi Mengenai Realitas Kemandirian Santri Di Pondok Pesantren Al-Istiqlal Cianjur Dan Pondok Pesantren Bahrul Ulum Tasikmalaya). Pendidikan Agama Islam -Ta'lim Vol. 10 No. 2 - 2012, 10(2), 124-127.

Ulum, M. (2018). Pembentukan Karakter Siswa Melalui Pendidikan Berbasis Pondok Pesantren. Evaluasi. Vol 2. No.2, September 2018, 2(2), 382-397.

Usman, H. (N.D.). Metodologi Penelitian Sosial. Penerbit Media Sahabat Cendekia.

Wijaya, R. (2015). Hubungan Kemandirian Dengan Aktivitas Belajar Siswa. Jurnal Penelitian Tindakan Bimbingan \& Konseling, 1(3), 40-45.

Zaenuri, Z., \& Prastowo, A. (2021). Peran Guru Dalam Perencanaan Pembelajaran Berbasis Aplikasi Zoom Meeting Di Sekolah Dasar. Edukatif: Jurnal Ilmu Pendidikan, 3(4), 1734-1744. Https://Edukatif.Org/Index.Php/Edukatif/Article/View/654. 